\title{
IDENTIFICATION OF FOREST SOILS ON AERIAL PHOTOGRAPHS
}

\author{
BY D. BURGER
}

D. (Dys) Burger, born in Ambarawa (Java, Indonesia) in 1923, spent a major part of his life in Indonesia and was in Japanese civil internment camps from 1942-1945. He received a Master's degree in Forestry of the Temperate Region (Landbouwkundig Ingenieur) from the State Agricultural University, Wageningen, Netherlands, in 1952. Since 1953 he has been employed by the Ontario Department of Lands and Forests as a member of the Site Section of the Division of Research. His field of research entails the study of site and its influence on the distribution and performance of forest tree species, and the study and development of techniques for mapping forest sites.

\section{ABSTRACT}

A stereoscopic image of the land is obtained by examining aerial photographs through a stereoscope. Three major components of the stereoscopic image, namely relief, vegetation and land use, are used to identify forest soils in terms of parent material (texture and mineralogical composition), moisture regime, and depth to bedrock. Field knowledge of the forest ecology and of the geology of the area under consideration are basic requirements.

\section{INTRODUCTION}

Aerial photographs are used for the identification and mapping of soils. In this paper a technique will be outlined for the identification of soils, with special emphasis on those features which influence forest growth, hence the use of the term forest soil.

The discussion will be centered around the stereoscopic image, i.e. what the interpreter sees on aerial photographs with the aid of a stereoscope. An outline will be given of the use of three components of the stereoscopic image, namely relief, vegetation, and land use for the identification of forest soils.

Before commencing on the interpretation of aerial photos, one should first consider which features of the soil are significant for tree growth and at the same time can be identified on the photos. It is beyond the scope of this paper to discuss in full the interrelationships of forest and soil and to present the reasons why the Site Research Section of the Ontario Department of Lands and Forests uses only three soil features (parent material, moisture regime, and depth to bedrock) in its province-wide scheme for mapping forest sites. It is felt, however, that some reasons should be presented, if only to illustrate the choice. Trees require from the soil: nutrients, water and rooting space.

The nutrients supplied by the soil not only depend on the texture and the mineralogical composition of the parent material, but also on the kind and intensity of biochemical and physical processes as influenced by local climate and vegetation. These processes are highly variable, while the texture and mineralogical composition of the parent material are more stable and can, therefore, be conveniently used for an initial breakdown of the land. Moreover, they are closely related to the mode of deposition and bedrock types and Paper accepted for publication June 28, 1956. 
can, therefore, be recognized relatively easily on aerial photographs if the photo interpreter has a knowledge of the geological history of the area under consideration.

As the amount of water available for tree growth changes with the seasons and from year to year, soil water should not be rated according to the amount available at a certain time, but rather for the whole length of the growing seasons. This rating is known under the term moisture regime. It can be evaluated through a study of the soil profile The moisture regime not only depends on texture and compaction of the soil material-Hills' permeability (1), later called pore pattern (2) - but also on the degree of slope, the position on the slope and the depth to impermeable layers or bedrock. The following broad moisture regime classes may be used:

dry during part of the growing season, e.g. on deep sand plains or on narrow ridge tops

fresh adequate water throughout the growing season, e.g. level deep loam or on middle slopes

moist excess of water in the upper soil horizons during part of the growing season, e.g. at the bottom of slopes

wet excess of water in the upper soil horizons during the whole growing season, e.g. swamps, valley bottoms.

The available rooting space is much influenced by impenetrable soil layers, frequently by the bedrock. Significant depth to bedrock classes have been established for various parent materials (3).

Depth to Bedrock Classes

\begin{tabular}{|c|c|c|c|}
\hline Clay & Loam & Sand & Organic \\
\hline $0.1^{\prime \prime}$ to $1 "$ & $0.0^{\prime \prime}$ to $2^{\prime \prime}$ & $0.0^{\prime \prime}$ to $3^{\prime \prime}$ & $0.0^{\prime \prime}$ to $2^{N}$ \\
\hline $1.0^{\prime \prime}$ to $6^{\prime \prime}$ & $2^{\prime \prime}$ to $12^{\prime \prime}$ & $3^{\prime \prime}$ to $18^{\prime \prime}$ & $2^{\prime \prime}$ to $36^{\prime \prime}$ \\
\hline Shallow____ $6^{\prime \prime}$ to $2^{\prime}$ & $12^{\prime \prime}$ to $3^{\prime}$ & $18^{\prime \prime}$ to $4^{\prime}$ & $36^{\prime \prime}$ to $7^{\prime}$ \\
\hline Moderately deep..... $2^{\prime}$ to $7^{\prime}$ & $3^{\prime}$ to $10^{\prime}$ & $4^{\prime}$ to $12^{\prime}$ & $7^{\prime}$ to $12^{\prime}$ \\
\hline Deep & over $10^{\prime}$ & over $12^{\prime}$ & over $12^{\prime}$ \\
\hline
\end{tabular}

The description of soil features and their interrelationships to the climatic and vegetative components of site is presented in greater detail in the publications by $\mathrm{G}$. A. Hills. $(1,2,3)$

In the following paragraphs an attempt will be made to indicate how these three main soil features-parent material, moisture regime, and depth to bedrock-can be identified on aerial photographs.

The commonly used panchromatic photographs with a scale 1 inch $=20$ chains $(1: 15,840)$ are suitable for this work.

\section{Components of THE Stereoscopic IMAGE}

The stereoscopic image is the three-dimensional picture of the land which the photo interpreter sees on aerial photographs with the aid of a stereoscope.

Analyzing the stereoscopic image, three groups of components can be distinguished: 
(1) Relief: (a) macrorelief, such as hills, ridges, valleys, terraces, plains, rivers, lakes, etc.

(b) microrelief, such as small bedrock outcrops, minor depressions and elevations, waterfalls, rapids, lake shores, etc.

(2) Natural vegetation: tree species, stand density and tree height, swamps, muskegs, etc.

(3) Land use: farms, roads and railroads, excavations, cut-over areas, etc. tions.

For the interpretation all these components are used, mostly in combina-

\section{RELIEF AS AN INDICATOR OF SOIL}

One has to keep in mind that the stereoscopic image, as seen on aerial photos with the normally used scale of $1: 15,840$, gives an exaggeration of the actual relief when a field stereoscope is used. Also the relief is distorted along the edges of the photos.

Parent material is mainly determined through the interpretation of the distribution, shape and size of hills, ridges, valleys, plains and terraces and especially their relative position in the macrorelief.

In a glaciated area like Ontario one can expect glacial till deposits on hills, ridges and elevated flats, while in the relatively lower position glaciofluvial deposits of sand and gravel can be expected. The tills have, in general, a large amount of silt and clay which results in better moisture and nutrient conditions than that found in waterlaid sand and gravel from which the fine particles have been removed. Very large eskers and terminal moraines composed of sand and gravel can also occupy relatively elevated positions. Eskers, which can be recognized by their sinusoidal or snake-like form and which are often accompanied by kettle lakes, and the occurrence of terraces and plains, will give some idea of the extent and the proportions of the glacio-fluvial streams in which sand and gravel were deposited.

Along the shores of the Great Lakes, silt and clay deposits are found. They are deposits of former larger extensions of those lakes in inter- and post-glacial ages. Once the maximum height of the lake deposits has been established in the field, the interpreter can eliminate occurrence of those deposits at higher elevations. The situation becomes more complicated where these materials were picked up by the land ice and deposited on hills during later ice-advances. A more intimate field knowledge of the glacial history is needed in those cases.

Waterlaid silt and clay deposits are mostly level, which is especially noticeable where they have been cleared for farming.

Erosion patterns are useful in the distinction between sand and silt or clay plains.

Recognition of bedrock types, such as basalt mesas or tilted gneiss, is based on both macro- and microrelief. In limestone areas the surface of very shallow cleared land shows a peculiar rough texture on the photographs, pos- 
sibly due to differences in degree of dissolving of the limestone in higher and lower spots of the microrelief.

Position in the relief (hilltop, bottom of a slope, etc.) is valuable in the determination of moisture regime. Of course, the parent material should be known before the moisture regime can be determined, especially for the upland sites; a ridge of waterlaid sand is mostly dry, while a similar ridge of deep glacial loamy till will be classified as fresh.

The depth to bedrock can, to a certain degree, be determined by interpretation of the microrelief. For instance, the smooth surface and long gentle slopes as found in drumlins indicate deep till deposits, while ridges with narrow crests and steep slopes have shallow soils. Outcrops and small faults of the bedrock, and the sometimes distinct stratification of tilted gneiss and schist are all indicators of shallow soil (approximately less than 3 feet deep); a deep soil would cover the faults and minor bedrock relief completely.

Vegetation as an Indicator of SoIL

In forested areas tree species, stand density and tree height aid in the identification of soil. The soils on which a given tree species is found vary from one climatic region to another, e.g. a species may grow on a relatively moist soil in southern regions, while it would prefer the drier soils in regions to the north.

Within a site region $(2,3)$ species distribution is fairly closely related to moisture regimes. On dry soils other species are found than on wet soils. Thus the ability of the photo interpreter to identify species from aerial photographs is important, as these species will be used as indicators of moisture regime.

Balsam poplar (Populus balsamifera $\mathrm{L}$.), which has a fairly large and darktoned crown on aerial photographs, can be used to separate the moist soils from the wet soils in the flat clay plains of northeastern Ontario, where it is often extremely difficult to detect changes in degree of slope, particularly at the edges of the photos, or when the photo is even slightly tilted. In Algonquin Park, the highlands south of the Middle Ottawa River valley, yellow birch (Betula lutea Michx. f.), distinguishable by its large dark-toned crown, prefers the fresh and moist sites. Red oak (Quercus borealis Michx. f.) and red maple (Acer rubrum L.), with smaller and lighter-toned crowns, tend to occupy the drier, warmer upper slopes.

It should be kept in mind, however, that stands of various cover types can occupy the same moisture regime as stand composition is to a considerable degree influenced by history, availability of seed, etc. A conifer-aspen stand on a lower slope near a swamp in Algonquin Park can occur on the same moisture regime as a stand of sugar maple - yellow birch (Acer saccharum Marsh. - Betula lutea Michx. f.) depending on fire history and the availability of seed. Interpretation of the position in the relief (lower slope), and the knowledge of the requirements of the tree species within the Lake HuronMiddle Ottawa River site region would in both these cases suggest a moist soil.

The use of forest vegetation in the interpretation of moisture regimes is particularly useful where the relief cannot be used by itself. For instance, upper 
and lower flats can be dry, fresh, moist or wet, or combinations of moisture regimes; upper slopes and ridge tops can be either shallow and dry, or deep and fresh. An analysis of the forest cover with a knowledge of the ecology of the tree species will enable the interpreter to make his decision.

Unfortunately, not all species can be used for the determination of moisture regimes. Pure aspen (Populus tremuloides Michx. and P. grandidentata Michx.) and white birch (Betula papyrifera Marsh.) stands occupy a wide range of soils, and the only clue to moisture regimes in those cases is the position in the relief. A field knowledge of the relationships between length and steepness of slope and moisture regime within a certain parent material is necessary in these areas.

In the Clay Belt of Northern Ontario, stand density in black' spruce (Picea mariana (Mill.) BSP.) swamps can be used to distinguish the wet soils from the very wet or saturated soils. The increase in moisture regime in those swamps is not only accompanied by a decrease in stand density, but also by a decrease in tree height. It is sometimes difficult to decide if changes in height are due to moisture regime or frost, or simply show differences in age because of a different fire history. A decrease in tree height due to fire, however, is more abrupt than one caused by an increase in moisture regime, or one which is due to the influence of frost.

Depth to bedrock can often be determined by observing changes in stand composition. Shallow soils often show changes in stand composition over short distances on a relatively level relief. The stand composition is mainly influenced by changes in moisture regimes brought about by the close proximity of an undulating bedrock relief. In deep soils, moisture regime is not as much influenced by the bedrock relief; consequently changes in moisture regime and, therefore, also changes in stand composition are more gradual or absent.

Stand density is also an indicator of soil depth, especially where the stand is very open. The very open stands on ridge tops mostly indicate very dry and very shallow soils. Of course, overmature stands which are breaking up or partially cut stands are also open, but other clues, such as topography, haul and skid roads, proximity to farms may be helpful in the correct interpretation of stand density.

\section{LAND USE AS AN INDICATOR OF SOIL}

Excavations are often good indicators of soil material, for instance of gravel. They can be misleading. Many small exploration pits for mining occur, or rock is excavated in some cases for building purposes. Glacial till is often used for road fill. Thus the excavations are not very reliable by themselves; however, with an observation of their place in the macrorelief a definite determination of the soil material can be made.

Cleared land gives much information on soil depth because the microrelief can be closely examined. A smooth surface free of bedrock outcrops may indicate a fairly deep soil.

Roads, not the straight highways, but the older roads and especially old logging roads, are helpful in the determination of soil depth. Many turns and 
curves suggest bedrock outcrops, faults or large boulders which cannot always be seen on the aerial photographs, because they are concealed by the vegetation.

Highway and railway cuts can be useful for soil depth determination, but only if the photo has a wide range of tones. In those cases a smooth surface of the cut may indicate a deep soil, while a rough surface could suggest bedrock.

\section{COMPONENTS USED IN COMBINATIONS}

A single component of the stereoscopic image may have several interpretations. Therefore, the interpretation of aerial photographs is not based so much on a single component as on a weighing of several components in combination, which eliminates all but one possibility.

Suppose two long slopes in Algonquin Park are studied on aerial photographs. The first slope has a relative position in the macrorelief which suggests that it is covered by glacial till rather than by waterlaid sand. On moist soil at the bottom of the slope large dark-toned crowns of yellow birch and lightertoned crowns of sugar maple can be observed. On the slope, where the soil is fresh, the same cover type occurs, although the percentage of dark-toned yellow birch crowns diminishes towards the upper slope while the lighter-toned crowns of sugar maple and probably of beech (Fagus grandifolia Ehrh.) increase in number. The dry ridge top shows a different cover type with a lower crown density and consisting mainly of red maple, red oak, and white ash (Fraxinus americana L.) which have fairly light-toned and fairly small crowns.

The second slope has the same length and steepness and the same parent material and aspect, however, the cover types are distributed quite differently. The yellow birch does not occur so high on the slope and the species, which normally occupy the dry ridge tops, are found on the upper slopes instead of on the ridge top; the ridge top is occupied by an open stand of conifers with or without an admixture of hardwoods, which is indicative of a very dry soil.

The difference in distribution of moisture regimes on the two slopes can only be caused by differences in soil depth. Thus from an analysis of relief and vegetation the soil depth is determined.

In some areas extensive fires occurred after logging. After the fire aspen and birch seeded in and almost solid stands of these pioneer species cover till slopes and sand flats and valleys. The interpreter has no vegetation that can help him in the determination of the moisture regime and parent material of these depresssions which could be composed of fresh or moist till, or dry deep waterlaid sands. To decide on the moisture regime and parent material, the interpreter has to build up a theory of the geological history of the area. If the low area under consideration is at the same level as or lower than sand or gravel deposits (eskers, terraces, etc.) within the vicinity and is connected with those deposits via valleys, then the area probably consists of sand or gravel. Then, within the burned area, the interpreter will look for small terraces, erosion patterns, remnants of eskers, kettle lakes, etc. to decide on the parent material. Knowing the parent material, he will be able to determine the 
moisture regime considering the microrelief features. In this case relief and knowledge of the geology are used in the interpretation.

Glacial history is used extensively in the Clay Belt of Northern Ontario. Any isolated north-south oriented ridge is suspected of being an esker (indicating deep sand and gravel deposits). Presence of kettle lakes, terraces, etc., even several miles to the north or south, may lead to the determination of these sand trains. These eskers in the Clay Belt are often covered by clay and silt, thus hiding the pronounced outlines of the eskers. Field knowledge of the glacial history and bedrock formation should provide the information of what can be expected in the area under observation.

\section{ConCLUSIONS}

Components of the stereoscopic image, such as relief, vegetation and land use, are used in combinations and individually to identify forest soils on aerial photographs.

The use of relief for the identification of forest soils requires a field knowledge of the influence of geological processes on the distribution of parent materials and of the influence of relief on moisture regimes for certain parent materials.

The use of vegetation for the identification of forest soils requires a knowledge for each species of its soil requirements and of the species with which it associates, on the various soils. It should be kept in mind that the requirements of the tree species vary with climatic regions, and that consequently the identification of forest soils on aerial photos is not possible without a knowledge of the local conditions.

The use of the land use component for the identification of forest soils requires a knowledge of the cultural development of the area under consideration.

\section{ACKNOWLEDGEMENTS}

The author wishes to extend his thanks to both Professor D. V. Love, Faculty of Forestry of the University of Toronto, and Mr. G. A. Hills, Research Division of the Ontario Department of Lands and Forests, for their interest and encouragement. Constructive criticism of the manuscript by G. A. Hills and K. A. Armson of the Faculty of Forestry of the University of Toronto, G. Pierpoint and R. D. Carman, both with the Ontario Department of Lands and Forests, was most helpful, while the editorial advice by G. Pierpoint was much appreciated.

\section{Literature Cited}

1. HILLS, G. A. 1950. The Use of Acrial Photographs in Mapping Soil Sites. Forestry Chronicle 26:4-37.

2. HILLS, G. A. 1952. The Classification and Evaluation of Site for Forestry. Research Report No. 24, Ontario Department of Lands and Forests.

3. HILLS, G. A. 1954. Field Methods for Investigating Site. A. The Detailed Site Description Form, Site Research Manual 4. Ontario Department of Lands and Forests. 